\title{
Curriculum 2013 - Based Assessment to Measure Critical Thinking Skills of Science Teacher at Junior High Scholl Donggala Regency, Indonesia
}

\author{
Ika Istadewi* \\ Biology study program, Faculty of Teacher Training and Education, Tadulako University, \\ City of Palu, Central Sulawesi, Indonesia \\ Andi Tanra Tellu \\ Biology study program, Faculty of Teacher Training and Education, Tadulako University, \\ City of Palu, Central Sulawesi, Indonesia \\ Mohamad Jamhari \\ Biology study program, Faculty of Teacher Training and Education, Tadulako University, \\ City of Palu, Central Sulawesi, Indonesia \\ Amiruddin Kasim \\ Biology study program, Faculty of Teacher Training and Education, Tadulako University, \\ City of Palu, Central Sulawesi, Indonesia
}

\begin{abstract}
This study aimed to develop a curriculum 2013 - based assessment to measure the critical thinking skills of qualified science teachers in junior high schools with valid, practical and effective criteria. This research method consists of preliminary studies, instrument development and expert team assessment. The sample in this study was 107 science teachers at the Donggala Regency Middle School. The curriculum 2013 - a based assessment that was developed consists of curriculum 2013 analysis, science materials, grids, question cards, questions, rubrics and validation sheets. The data analysis technique used anates software program. The results of the study found that curriculum 2013 - based assessment instruments reviewed by the validator team and were appropriate to use. The quality of the test can be seen in the average value of the critical thinking assessment of 0.71 with a valid category. Feasibility assessment developed for critical thinking test of 0.83 in the Very High category. The curriculum 2013 - based test assessment for science teachers obtained critical thinking test products were that very effective.
\end{abstract}

Keywords: Development, Curriculum 2013 -Based Assessment, Critical Thinking, Science Teachers.

DOI: $10.7176 / \mathrm{JEP} / 10-30-06$

Publication date:October $31^{\text {st }} 2019$

\section{Introduction}

Education is an important indicator to measure the progress of a nation that wants to be placed in a dignified and modern world, so the first thing to do is to develop education that has relevance and competitiveness for all children of the nation. Life skills that need to be developed through the education process are thinking skills. A person's ability to succeed in life is determined by thinking skills, especially in solving life's problems. Thinking is an activeness of the human person which results in discoveries that are directed towards a goal. Thinking skills have an important position in learning the curriculum (Swartz and Carol, 2014). Thinking skills are needed to face the demands of changing times (Malik, 2018).

The problem faced by the world of education is the weakness of the teacher assessment process so that it often goes unnoticed (Wahyuningsih, 2017). Based on the results of observations and interviews, science subject teachers did not understand how to develop critical thinking skills because they were not empowered. Furthermore, the education system also does not teach how to think at a high level. To measure the achievement of quality standards of education can be started from analyzing each component that can shape and influence the assessment process, one of which is a component of science subject teachers. Improving the quality of education in terms of teacher thinking ability is always improved by developing curriculum 2013 - based assessments.

The assessment plays a very important role regarding the effectiveness of the assessment process. In general the assessment has three functions, namely 1) to measure progress; 2) to support the preparation of plans; and 3) to improve or make improvements (Uno, 2012). Because of assessment instruments importance, it is required to develop assessments that can improve the critical thinking skills of science subject teachers so that teachers achieve thinking skills.

The teacher competency test for science subjects in 2015 showed that the composition of the 2015 UKG test 
material instruments was $30 \%$ pedagogical competence and $70 \%$ professional competence or 24 pedagogical questions and 56 professional questions. Therefore, science subject teachers in Donggala Regency Middle School to develop critical thinking skills through 2013 curriculum-based assessment tests with curriculum 2013 based science materials that are designed appropriately and systematically, so the goal will be easily achieved. The initial step to improve the assessment process is by developing a curriculum 2013 - based assessment so that it can measure the critical thinking skills of teachers so that they can solve the problems faced in the rapidly developing world of education. In the context of the assessment, critical thinking is necessary for successful assessment.

Based on the results of the study above, the researcher concluded that to measure critical thinking skills, it requires the existence of an assessment. This is important because in schools, science subject teachers are the main evaluators, so it is important for science subject teachers to have understanding and skills related to curriculum 2013 - based assessments. In other words, the success of a curriculum to be achieved depends on the skills of teachers in an effort to realize everything in the curriculum 2013.

This research aimed to develop a curriculum 2013 - based assessment in order to measure the critical thinking skills and metacognition of science teachers at Donggala Regency Middle School with valid, practical and effective criteria.

\section{Method}

This research used research and development design that focused on the development of curriculum 2013 - based assessment to improve the critical thinking skills of science subject teachers in Donggala Regency Middle School, which refers to the Plomp development model (2013) that consists of several phases, namely (1) the initial investigation phase, (2) design phase, (3) realization, (4) test, evaluation and revision phase and (5) Implementation. The analysis phase used Anates software version 4.0.5 developed by (Drs Tarno To, M.Pd and Yudi Wibisono., S.T). This instrument was validated by three experts. Data collection tools used were validation sheets and critical thinking description tests. All data collected from the validation process would be analyzed descriptively and qualitatively. The results of the analysis from the validation sheet and critical thinking description test were used as reference material for revisions, so that the curriculum 2013 - based assessment instrument was obtained to measure the critical thinking skills of science subject teachers who met valid criteria. The instrument was already valid, then tested on 107 science teachers who had implemented the curriculum 2013.

\section{Results}

\section{Initial investigation phase}

Table 1. Respondents Based on Curriculum 2013 Investigation

\begin{tabular}{lcc}
\hline & $\mathrm{n}(107)$ & $(\mathbf{\%})$ \\
\hline Curriculum implementation (year) & 26 & 14.46 \\
2015 & 28 & 17.29 \\
2016 & 23 & 7.14 \\
2017 & 30 & 61.11 \\
2018 & & 75.57 \\
Status & 64 & 24.43 \\
Civil Servant & 43 & 48.68 \\
Honorary & & 51.68 \\
Gender & 37 & 15.07 \\
Male & 70 & 53.10 \\
Female & & 24.86 \\
2013 Curriculum Training Attendance & 15 & \\
Never & 57 & 11.64 \\
1 time & 26 & 42.06 \\
2 times & & 26.98 \\
UKG Attendance & 15 & 16.94 \\
Never & 37 & 2.38 \\
$1-2$ times & 26 & \\
$3-4$ times & 20 & 9 \\
$5-6$ times & 96 & \\
More than 7 times & 96 & \\
\hline
\end{tabular}

The results showed that Table 1 contained the distribution of respondents in terms of aspects of the implementation of the 2013 curriculum implemented by 35 schools in 2018 with a total of 30 people or $61.11 \%$. In terms of status, there were 64 civil servants or $75.57 \%$ and 43 honorary teachers or $24.43 \%$. Frequency of 
respondents that have attended UKG were the majority of respondents who have attended training 1-2 times, as many as 35 people or $42.06 \%$.

\section{Realization Stage}

Curriculum 2013 - based assessment to measure critical thinking skills based on characteristics namely material, construction and language.

a. Material Expert Validation

The material expert validation on the 2013 curriculum-based assessment instrument to measure the critical thinking skills of science subject teachers was carried out by Mr. Dr. Mursito S. Bialagi, M.Pd., and Mrs. Lilis Tangge, MP., as lecturers in Biology Education. Based on the results of material expert validation obtained the following values:

Table 2 Percentage of Material Expert and Evaluation Expert

\begin{tabular}{|c|c|c|c|c|}
\hline \multirow{2}{*}{ Aspect } & \multicolumn{2}{|c|}{ Material Expert Validation } & \multicolumn{2}{c|}{ Evaluation Expert Validation } \\
\cline { 2 - 5 } & \multicolumn{2}{|c|}{ Percentage } & \multicolumn{2}{c|}{ Percentage } \\
\cline { 2 - 5 } & Before Revision & After Revision & Before Revision & After Revision \\
\hline Content Feasibility & $52.77 \%$ & $80.55 \%$ & $95 \%$ & $98.33 \%$ \\
\hline Construction Feasibility & $63.88 \%$ & $72.22 \%$ & $87.50 \%$ & $95.83 \%$ \\
\hline Language Feasibility & $69.44 \%$ & $80.55 \%$ & $79.16 \%$ & $95.83 \%$ \\
\hline Average & $\mathbf{6 2 . 0 3 \%}$ & $\mathbf{7 7 . 7 7 \%}$ & $\mathbf{8 7 . 2 2 \%}$ & $\mathbf{9 6 . 6 6 \%}$ \\
\hline
\end{tabular}

Table 2 shows that an increase in content feasibility of $27.78 \%$ after revision, construction feasibility also increased by $8.38 \%$ after revision, and language feasibility increased by $11.11 \%$ after revision based on material expert judgment. The evaluation expert also showed an increase in content feasibility of $3.33 \%$ after the revision, construction feasibility also increased by $8.33 \%$ after the revision, and the language feasibility increased by $16.67 \%$ after the revision.

Evaluation and Revision Phase

The curriculum 2013 - based assessment instrument to measure the critical thinking skills of science subject teachers at Donggala Regency Middle School during the evaluation phase showed that the response of science subject teachers to the quality of the curriculum 2013 - based assessment instrument had no obstacles. Percentage data related to the evaluation of each research variable is presented in each dimension of the questionnaire questions. So that the presentation of data is systematic, it is presented based on questions separately.

Table 3. Respondents' responses on instrument developed

\begin{tabular}{lccc}
\hline & Respondents' responses & $\mathrm{n}(107)$ & $\mathbf{( \% )}$ \\
\hline Strongly Agree & 32 & 17.98 \\
Agree & 73 & 58.82 \\
Disagree & 2 & 18.78 \\
\hline
\end{tabular}

Table 3 shows the majority of respondents namely 73 people (58.82\%) strongly agreed on 2013 curriculumbased assessment instrument developed. 32 people (17.98\%) agreed. But there were also respondents who stated they disagreed by 2 people (18.78\%).

Validity and Reliability of Instruments

Table 4. Validity Test Results of Critical Thinking Skills

\begin{tabular}{|c|c|c|c|c|}
\hline \multirow{2}{*}{$\begin{array}{l}\text { Question } \\
\text { Number }\end{array}$} & \multicolumn{2}{|c|}{ Validity Test } & \multicolumn{2}{|c|}{ Reliability Test } \\
\hline & Correlation coefficient & Description & Reliability & Description \\
\hline 1 & 0.707 & Valid & \multirow[t]{10}{*}{0,83} & \multirow[t]{10}{*}{ Reliable } \\
\hline 2 & 0.549 & Valid & & \\
\hline 3 & 0.426 & Valid & & \\
\hline 4 & 0.608 & Valid & & \\
\hline 5 & 0.749 & Valid & & \\
\hline 6 & 0.658 & Valid & & \\
\hline 7 & 0.525 & Valid & & \\
\hline 8 & 0.695 & Valid & & \\
\hline 9 & 0.622 & Valid & & \\
\hline 10 & 0.529 & Valid & & \\
\hline
\end{tabular}

Table 4 shows that the instrument developed was valid and had a very high level of reliability $(0.70<$ n 0.90

$=$ High) so that it was feasible to be used as a research data collection tool. 
Difficulty Level and Discrimination Power

Table 5. Categories of Difficulty Level and Discrimination Power on Critical Thinking Skills

\begin{tabular}{|c|c|c|c|c|}
\hline & \multicolumn{2}{|c|}{ Difficulty Level } & \multicolumn{2}{c|}{ Discrimination Power } \\
\hline $\begin{array}{c}\text { Question } \\
\text { Number }\end{array}$ & $\begin{array}{c}\text { Difficulty Index } \\
(\%)\end{array}$ & Difficulty Level & Discrimination Power Value (\%) & Interpretation \\
\hline 1 & 66.21 & Medium & 28.97 & Very High \\
\hline 2 & 55.17 & Medium & 27.59 & Very High \\
\hline 3 & 56.90 & Medium & 17.24 & Very High \\
\hline 4 & 46.21 & Medium & 31.72 & Very High \\
\hline 5 & 67.59 & Medium & 34.48 & Very High High \\
\hline 6 & 68.28 & Medium & 28.97 & Very High \\
\hline 7 & 63.79 & Medium & 22.76 & Very High \\
\hline 8 & 66.55 & Medium & 31.03 & Very High \\
\hline 9 & 73.79 & Easy & 23.45 & Very High \\
\hline 10 & 68.97 & Medium & 26.21 & The \\
\hline
\end{tabular}

Table 5 shows that there are 9 items had medium criteria, namely 1, 2, 3, 4, 5, 6, 7, 8 and 10. The difficulty of research instrument was approximately 0.7 which means that if confirmed with the criteria interpretation above, it can be stated that the instrument used in this research had a level of difficulty test with the category of $0.3<\mathrm{P} \leq 0.7=$ Medium. Based on the results of discrimination power analysis, it was obtained 10 items with Very High criteria.

\section{Discussions \\ Material Expert Validation}

The assessment of the two validator teams can be confirmed as one of the findings in this research namely the assessment of material experts at an early stage on content feasibility obtained a score of $52.77 \%$, construction feasibility obtained a score of $63.88 \%$ and the language feasibility obtained a score of $69.44 \%$. The empirical findings related to the quality of the assessment instruments directly influence the accuracy of the achievement of thinking ability results. Educational assessment standards are criteria on assessment mechanisms, procedures and instruments (Kemendikbud, n.d.). Assessment is a systematic and continuous process of activities to gather information about the process and results in order to make decisions based on certain criteria and considerations (Arifin, 2012). Critical thinking assessment instrument products for seventh grade junior high school students on the interaction of living things with the environment on validity and reliability (Dharmawati et al., 2016).

\section{Evaluation Expert Validation}

The results of the analysis on the 3 aspects of the evaluation experts are as follows, namely the aspect of content feasibility before revision obtained a score of $95 \%$ with very feasible criteria, in the construction feasibility obtained a score of $87.50 \%$ with very feasible criteria and the language feasibility obtained a score of $79.16 \%$ with feasible criteria. According to the suggestions and input obtained, a revision of the product developed was carried out. The content feasibilty obtained a score of $98.33 \%$, the construction feasibility obtained a score of $95.83 \%$ and the language feasibility obtained a score of $95.83 \%$ so that of the 3 aspects obtained very feasible criteria.

Empirical findings related to the assessment and analysis of the three evaluation experts on the curriculum 2013 - based assessment instrument to measure the critical thinking skills of science subject teachers at Donggala Regency Middle School had been declared very feasible or valid because obtained an average score of $96.13 \%$ and feasible at the stage of implementation. The results of the research supported the statement of Chasanah (2012) that the instrument is stated to be effective if the developed goals are achieved (Chasanah, 2012).

Product Test Results

This research objectively found that the development of curriculum 2013 - based assessment in the Anates test had been proven conclusively. Other results showed that curiosity and interest can make someone act according to their intrinsic drive, especially in exploring new things so they learn more broadly and deeply (Kashdan and Silvia, 2009). Critical thinking is a skill to carry out an examination of knowledge based on supporting evidence (Fisher, 2009).

Research on the influence of critical thinking skills on cognitive function, learning outcomes and student attitudes showd that students who were asked to think critically will learn better(Higgins et al., 2004). Research 
by Wenglinsky (2004) showed data from the National Educational Assessment Progress (NAEP) and Trends in International Mathematics and Science Study (TIMSS) that in the mathematics and science category, the types of questions that emphasize on reasons were given higher scores at all levels tested (Wenglinsky, 2004). Students who had an assessment about organizing their knowledge and experience to solve a problem got higher scores than average score in the Iowa Tests of Basic Skills (ITBS) and Illionis Goals Assessments Program (IGAP)(Newmann et al., 2001).

Reliability means consistent, that is, the measurement by one instrument that is carried out many times then the result is more efficient, reliable and valid measurements. Criteria for a good assessment instrument that considers aspects of validity and reliability based on the results of expert validation, limited trials, corrections and data analysis conducted is known that the critical thinking assessment of instrument developed had met the valid and reliable criteria, had very good readability criteria and good quality questions(Creswell, 2015).

Difficulty level test of curriculum 2013 - based assessment questions to measure the critical thinking skills of science teachers in Donggala Regency was performed. This is also in accordance with the opinion of Arikunto (2010) which stated that the higher the percentage that correctly answers a question, then question is easier and vice versa (Arikunto and Safaruddin, 2010). Based on this opinion, it can be concluded that the easier a question is, then many will answer the question correctly, whereas if the question is difficult, then only a few are able to answer the question correctly.

Based on the results of the analysis above, the difficulty level of the curriculum 2013 - based assessment tests of science teachers in the Donggala Regency referred to Bloom's taxonomy theory asserted that to develop one's thinking ability by paying attention to how to do the test correctly. If there are many test subjects who cannot answer correctly, the level of difficulty of the test is high, conversely, if only a few of the subjects cannot answer correctly, the difficulty level is low. The level of difficulty of the assessment test is expressed in the difficulty index of the test.

These findings are to measure the thinking skill as an evaluation tool developed is an evaluation tool used to determine the critical thinking skills of science subject teachers in junior high school science subjects. Evaluation tools developed, each question evaluates the skill to think critically for the description test. Based on expert validation, it can be seen that the evaluation tools developed theoretically had been appropriate to be used to measure the critical thinking skills of science teachers in Donggala Regency.

The dimensions of the curriculum 2013 - based assessment indicator development had been maximized. It can be seen by the distribution of answers that 32 respondents or $17.98 \%$ strongly agreed, 73 respondents or $58.82 \%$ agreed and 2 respondents or $18.78 \%$ disagreed.

Based on the findings above through the development stage, the assessment that has been made can be seen its development. Evaluation results can be used to determine appropriate alternatives in making decisions to improve performance in education units (Arikunto and Safaruddin, 2010). One of the requirements in conducting an evaluation is that the contents of the test must cover aspects of the achievement to be evaluated. The success of an evaluation activity is inseparable from the evaluation tools used. The evaluation tool that is often used in the assessment process is a test. The test results obtained will indicate whether or not the test used in order to measure the skills, knowledge, intelligence, abilities or talents possessed by individuals. One effort to develop good quality test questions is by analyzing items to measure critical thinking skills and metacognition of science subject teachers at Donggala Regency Middle School.

\section{Conclusion}

The curriculum 2013 - based assessment product that was developed to measure the critical thinking skills of science subject teachers had fulfilled the requirements for developing a quality test assessment product that is valid, practical and effective and provides new insights to educators as another way to understand thinking skills. Curriculum 2013 - based assessment products that had been reviewed by a verified validator team based on content, language and construction through expert judgment with Very High validity. The Curriculum 2013 based assessment product was declared effective in measuring critical thinking skills of science teachers at Donggala Regency Middle School

\section{Acknowledgments}

I would like to thank the Ministry of Ministry of Research, Technology and Higher Education for its strong support. The project name is Doctoral Grant Program at Tadulako University.

\section{Disclosure statement}

No potential conflict of interest was reported by the author.

\section{References}

Arifin, 2012. Evaluasi Pembelajaran. PT. Remaja Rosdakarya, Bandung. 
Arikunto, Safaruddin, 2010. Dasar-dasar Evaluasi Pendidikan Edisi Revisi. Bumi Aksara, Jakarta.

Chasanah, 2012. Pengembangan Perangkat Pembelajaran Matematika Model Cognitive Growth dengan Mengintegrasikan Nilai Karakter Bangsa untuk Meningkatkan Kemampuan Berpikir Kritis pada Siswa Kelas VIII. Universitas Negeri Semarang, Semarang.

Creswell, 2015. Penelitian Kualitatif \& Desain Riset. Pustaka Pelajar, Yogyakarta.

Dharmawati, D., Rahayu, S., Mahanal, S., 2016. Pengembangan Instrumen Asesmen Berpikir Kritis Untuk Siswa Smp Kelas Vii Pada Materi Interaksi Makhluk Hidup Dengan Lingkungan. J. Pendidik. Teori Penelit. Dan Pengemb. 1, 1598-1606. https://doi.org/10.17977/jp.v1i8.6677

Fisher, 2009. Berpikir Kritis Sebuah Pengantar. Erlangga, Jakarta.

Higgins, G.A., Ballard, T.M., Kew, J.N.C., Richards, J.G., Kemp, J.A., Adam, G., Woltering, T., Nakanishi, S., Mutel, V., 2004. Pharmacological manipulation of mGlu2 receptors influences cognitive performance in the rodent. Neuropharmacology 46, 907-917. https://doi.org/10.1016/j.neuropharm.2004.01.018

Kashdan, T.B., Silvia, P.J., 2009. Curiosity and Interest: The Benefits of Thriving on Novelty and Challenge. Oxf. Handb. Posit. Psychol. https://doi.org/10.1093/oxfordhb/9780195187243.013.0034

Kemendikbud, 2013. Materi Pelatihan Guru Implementasi Kurikulum 2013. Dirjen Dikdasmen Kemendikbud, Jakarta.

Malik, R.S., 2018. Educational Challenges in 21st Century And Sustainable Development. J. Sustain. Dev. Educ. Res. 2, 9-20. https://doi.org/10.17509/jsder.v2i1.12266

Newmann, F., Smith, B., Allensworth, E., Bryk, A.S., 2001. Instructional Program Coherence: What It is and Why It Should Guide Scholl Improvement Policy. Educ. Eval. Policy Anal. 23, 297-321.

Swartz, Carol, 2014. Developing And Assessing Thinking Skills the International Baccalaureate Project 2014. Oxford University Press, New York.

Uno, H.B., 2012. Assessment pembelajaran, Cet. 1. ed. Bumi Aksara, Jakarta.

Wahyuningsih, W.A., 2017. Evaluasi Program Kerja Pengawas Sd/Mi Di Upt Curup Kabupaten Rejang Lebong Propinsi Bengkulu. MANAJER Pendidik. 11.

Wenglinsky, H., 2004. Facts of Critical Thinking Skills? What NAEP Results Say. Educ. Leadersh. 62, 32. 